\title{
Making Japanese Language Learning Models through Multimedia-Based SCL Implementation
}

\author{
Ariani Tanjung \\ Business Administration Department, Politeknik Negeri Padang, Kampus Limau Manis, Padang, 2500, Indonesia \\ E-mail: arianitanjung.16@gmail.com
}

\begin{abstract}
This research is an action research, design in action research designed to looking fo solution to improve japanese teaching process. According to Karwono (2012). The Implementation of action research starting with awareness of the disturbing problem and cause prevent the achievment of education purpose an give dab impact from process and student grade when learning process aplied. Due to those problem then we set the focus of the problem more detail by collecting systematic data with relevan literature review. Things that must be considered is input, process, and output. If in learning process we find incomptability with education purpose or Curiculum then the process must be fixed for education goals, and especially vocational education system. Therefore I try to make a design in the form ofStudent centered learning based on multi media. For technology media using Flash MX, adobe premier, and adobe photoshop program.
\end{abstract}

Keywords-SCL; multimedia; Japanese

\section{INTRODUCTION}

System or teaching methode for every teacher have dofferent steps or style. Sytem that set by colege or Dikti is very helpful to arrange good and corrrect teaching strategy. In order to homogenize the teaching procedure steps must be folowed by lecturer is should make suitable RKPPS, SAP for each subject.

Based on those RKPPS and SAP, its easier to apply if based on sudent center learning (SCL) applied in media based learning. SCL is Olistik learning process aims to easier the lesson and associated wiith daily contex, even in social or cultural. Learning foreign lenguage is not only competency in theory required, but also in practicing like fluent in japanese conversation personally or group. SCL system emphasize in learning creativity and teacher is only as learning fasilitator. So that we can reaching five ideal teaching as follows : Relating, experiencing, applying, cooperating, transfering.

Alteration paradigma of SCL due to unsatisfied teaching experience, becouse its only focus on one way teaching design. Like teacher is only as coventional knowledge transferer (oneway traffic), while student only listening with minimal activity. Those way not give good motivation to student but give monotonous impresion. Student tend to be apathetic because of conventional learning system. Moreover those learning system feels stuffy. So SCL system can make student feels their conceptual ability fastly trained. To simplify creativity improvement i try to apply SCL based on Multimedia to simplify education tools.

Based on description above $\mathrm{i}$ would like to try teaching foreign language system combining SCL methode based on media. As we know defenition of media came from latin "Medium" means server, is send messege from sender to receiver. Some expert give some defenition about learning (schramm 1977) bring up that learning media is a mesengger technology that can be use to teaching needs. Meanwhile, Briggs (1977) conclude that learning media is physical to explain learning material like books, film, video, and etc. Meanwhile, national education association (1969) explain that learning media is comunication media in the shape of print, or see-hear, including 
hardware, from three opinion above we can conclude that learning media is everything that send the message, stimulaate the mind, feelings, and student will so we can push learning process of student. Brown (1973)explain that learning media that we use in learning process only using as teacher tools when every tools that we use is visual tools. Around 20's century visual utilization efforts are equipped with audio, and created na audio visual tools. in line with the development of science and technology (IPTEK), especially in education, now tools or learning usage more widespread and interactive, just like computer and internet. The method used is give learning material through IT based on multimedia. SCL methode and IT teching method motivates me to make a SCL learning model design program combine with IT learning multimedia based. To simplify education media by title "making Japanese language learning models through multimediabased SCL implementation".

\section{LITERATURE REVIEW}

As a research reference I try to combine between study reference SCL and teaching metodology IPTEK based as folows :

\section{A. SCL Methodology}

SCL activity which is studnet work individually or group to explore the problem, active to looking for knowledge not only as passive knowledge receiver (Harmoni \& Harumi, 1996). Based on those theory teacher as information gatekeeper, and student construct learning by active to finding the information needed. Meanwhile teacher switch the function as guides on sides : among others helping the student to access, organize, an d transfer all information to get the answer about problem in real live. $\mathrm{In} \mathrm{SCl}$ Methode focused on student needs and student indivudal activity. Techers only as a tutor in the class to support student effort, no $t$ for as center of attantion or learning center. SCL methode also as inspiration for student to use holiday to be more effective and usefull bu searchin information throught guide from lecture and electronic media such as TV, news paper, radio and internet. So that creating a harmony between students and lecturers. Because student sued to olace them self as a partner with the teachers in adecation world
(Alley, 1996) In this case SCL is the opposyte of teacher centered (Eaton.1994).

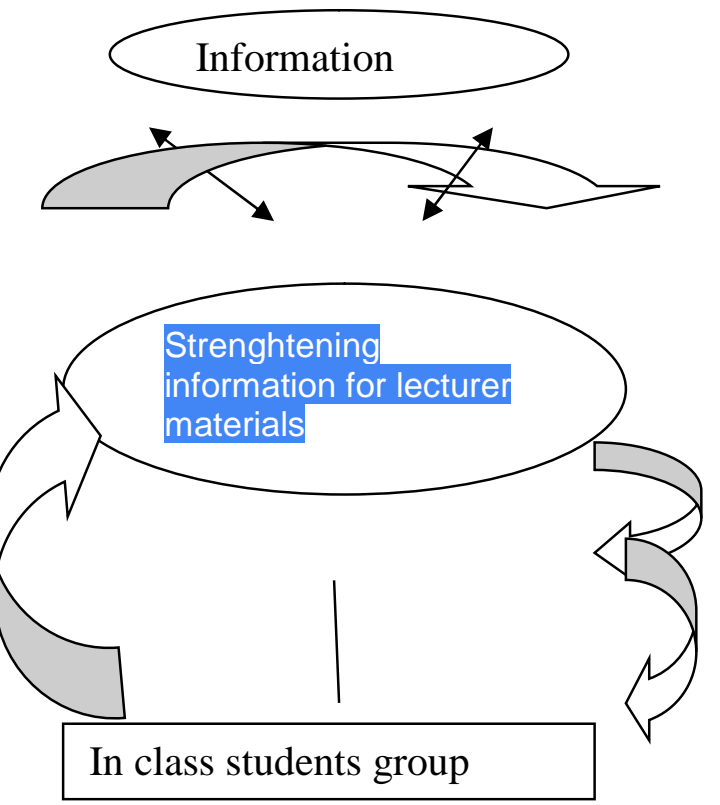

1) Systematic various Learning Towards two-way Assesment system. Learning sytem that came from teacher centered, or learning process focused on teacher, now its become Student centered learning, or become a learning centere focused on student. Based on explanation above teacher become student lecture, an trainers. To support SCL system must acompany with assesment asilmilation, from one-way assesment sytem to two-way assesment system. Based on learning system such as input, process, output, outcom and impact. In this caseinput contains with student as the assesment object, and dosen as that provise with teaching material, curiculum, and adequate learning system. Output can be measured with student grade. Output can be measured by criteria for graduate competence that must be mastered to simplify the student to apply for job. This criteria mark on study purpose every departement, impact can be measured, see, and reviewed from comunity, stackeholders, and alumni after they get a job.

Explanation of those learning system must be accompanied with complex assesment such as theory and practice. Thery contain with writing assesment and practice contains with student ability to speak and comunication.

2) Procedures for increasing passive students to be active in making presentations in learning Japanese. Generally factors affecting learning process is 
physiological and psycological. When physiological factor associated with physical condition called physical tone and physical function associated with five senses. Five senses that function properly will facilitate learning activity. In japanese learning usually use media audio visual such as tape recorder or video, as media for student to train adn listen correct japanese pronounciation to get maximal grade for thery and practice. Therefore, its very important to pay attantion to physiological factor. Meanwhile practice assesment closely related with physicological factor such as motivation, interest, skill, and behavior.

\section{- Interest}

According to (Slavin, 1994) that motivation as process for active human, Push to give direction, and to keep good behavior everyday. Can be siid that motivation is one of the factors that affect studen learning activity. Motivation is devide in to two taht is intrinsic is motivation taht came from within and last longer in everyone and more efective. According to adden $\mathrm{N}$ frndsen (Hayinah, 1992) whic is include in intrinsic motivation is :

1. Curiosity and explore the wide world

2. There is a positive $\&$ creative character that always want to go forward

3. There is a will to get achievment so get support from important people, like parents, sisters, teachers, etc.

4. There is needs to mastering the science that useful for them self and others.

Otherwise, eccentric motivation is outside factor but give willingness to study, such as praise, rules, and parents and teachers models.

Interest is the same with intelligence and motivation, because give influence with learning activity (According to Reber in Syah, 2003). Therefore in the context of learning in class, a teacher must be able to grip attention from student to support SCL system methode.

\section{- Attitude}

In learning process, human attitude can affect success of the learning process. Attidue is internal indication whis has an affective dimension like tendency to respond in a fixed way to objects, event, people, etc, positively or negative (Syah,20013). In this case student as object for teacher to transfer the knowledge or teacher as fasilitator must be able to be profesional an responsible in the class to make conducive class atmosphere.

\section{- Behavior}

Physiological factor is the last that can affect learning process is behavior (aptitude) can definite as potential ability that someone has to reach success in the future (Syah,2003). While according to Slavin (1994) behavior is general ability that student has to learn. Because of that behavior is one important component that very is dispensable for learning process, because of behavior is the most supportive thingsfor someone in choosing subject for their success. Physiological and psycological factor explained above is most important things to support SCL and it will implemented in learning foreingn language especially learning Japanese.

\section{RESEARCH METHODS}

All Design methode of this research is qualitative and quantitative. To proof this research we need Two years. First step is to progress learning process and to see skill and grade as a teacher or student in seeing skill, behavior. And second steps is to implemented multimedia program. Therefore I try to design the methode for this research as folows.

\section{A. Research}

The entire document should be in Times New Is implementation from curiculum in SCL method mapping based on vacational. Thiose curiculum designed based on empirical reserach in learning process. This research is one of the action research. Reserach design in action research purposes to looking for solution ti improve or fixes the process in learning japanese. In the implementation of Karwono (2012) , action research start with awareness of the problem, and hinder the achievement of education goals and can give bad impact in student learning process, or implemetation of a learning method.

From those awareness about the problem than we can specify problem focused by collecting real data systematically or doing relevan literature review. In this case we shoul focused in input, process, and output. If in japanese learning process we found incomtability with education purpose or curiculum need tobe fixed as soon as possible, for vacatiobal adeucation success. Based on 
explaination of theory description above, its clear if action research is inquiry to understand practicing and articulation practice philosophy to improve precticing.

\section{B. Population and Sample}

Population of this research is bussines Administration departement student consisting of business administration and travel agent Padang state polytechnic academicyear 2017/2018.

\section{Data Collection Technique}

A questionnaire will be given in the fisrt treatment so we can get first data about student learning habbit before treatment and after treatment.

\section{Data Analysis}

Analyze methode and technique using formal empirical data are qualitative and quantitative, it means we get the data based on learning in class

\section{RESULT AND DISCUSSIONS}

Questionaire for student divided in to 5 question will be attachend into instrument (76 question) as folows :

1. Student experient in learning japanese in university that using SCL learning method.

2. My own competence in learning Japanese in Polytechnic

3. Student believes in learning Japanese.

4. Student motivates to learning Japanese (why do you learning Japanese).

5. Japanese teacher's role based on student student opinion.

The five parts of the question above distribute to 143 students. They were given approval oppinion in five category as folows :

1. Strongly disagree

2. Disagree

3. Do not know

4. Agree

5. Strongly agree

What is obtained from these results ? because of $\mathrm{z}$ count is smaller $(-41,1093)$ with $\mathrm{z}$ table $(1.96)$ so $\mathrm{H}$ approve, means by using SCL methode there is difference in student grades.

TABLE I

STUDENT'S QUESTIONNAIRE NUMERICAL $\underline{\text { Mahasiswa }}$

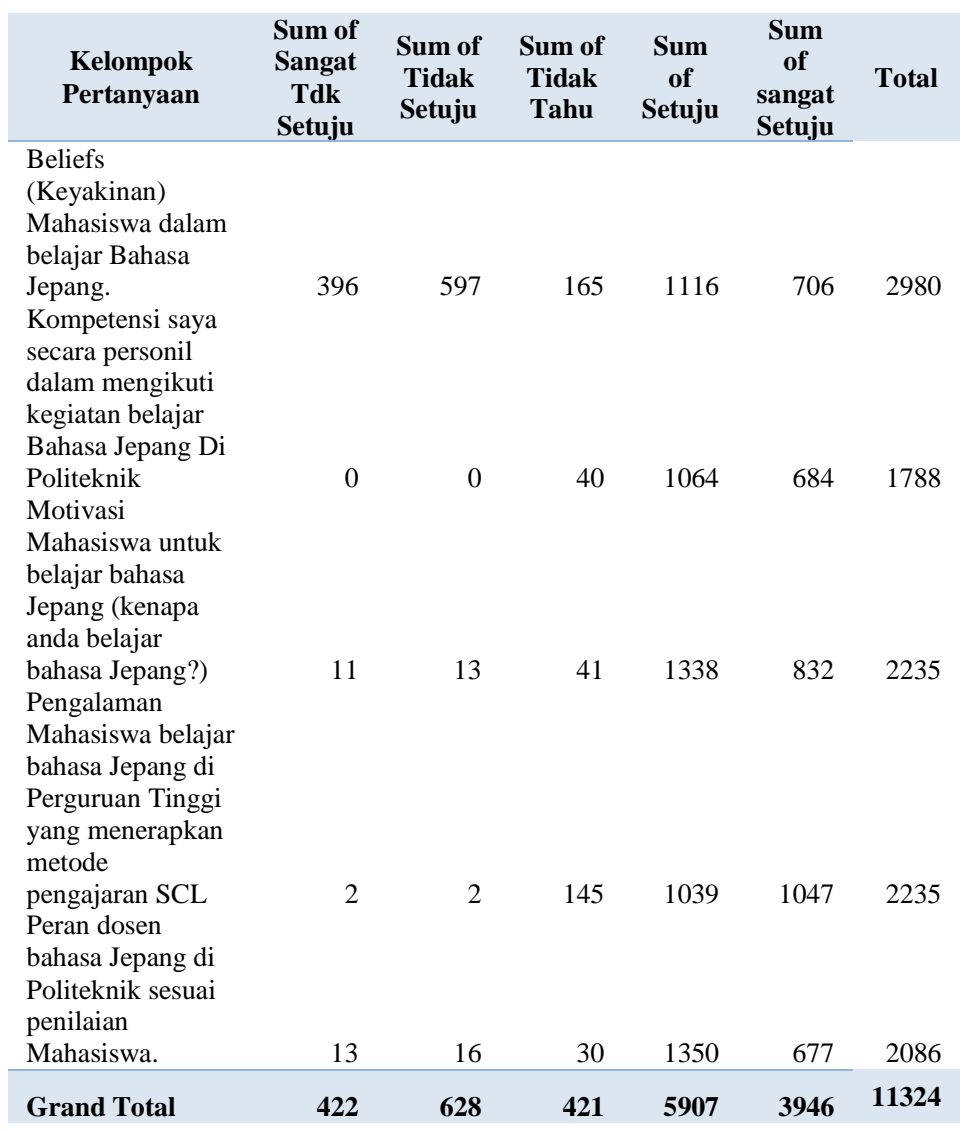

If it is grouped into percentage, it can be concluded that:

TABLE III

STUDENT'S QUESTIONNAIRE NUMERICAL: IN PERCENTAGE

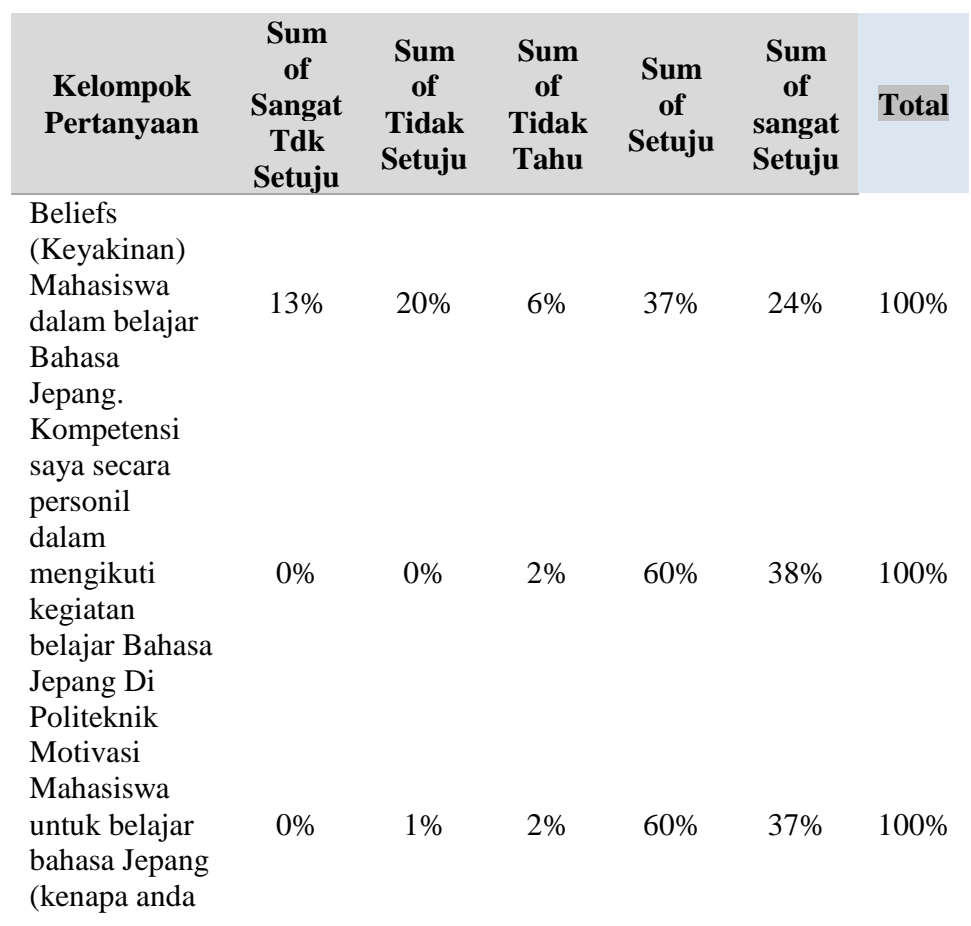

Grafik Angka

kuisioner dari

semua 
belajar bahasa

Jepang?)

Pengalaman

Mahasiswa

belajar bahasa

Jepang di

Perguruan

Tinggi yang

menerapkan

metode

pengajaran

SCL

Peran dosen

bahasa Jepang

di Politeknik

sesuai

penilaian

Mahasiswa.

$46 \%$

$47 \%$

TABLE IIIII

Z-TEST

z-Test: Two Sample

for Means

\begin{tabular}{lrr}
\hline & Variable 1 & \multicolumn{1}{c}{ Variable 2 } \\
\hline Mean & 63.4966443 & 78.38926174 \\
Known Variance & 39.4312 & 39.35183 \\
Observations & 149 & 149 \\
Hypothesized Mean & 15 & \\
Difference & -41.10936217 & \\
$\mathrm{Z}$ & 0 & \\
$\mathrm{P}(\mathrm{Z}<=\mathrm{z})$ one-tail & 1.644853627 & \\
z Critical one-tail & 0 & \\
$\mathrm{P}(\mathrm{Z}<=\mathrm{z})$ two-tail & 1.959963985 & \\
$\mathrm{z}$ Critical two-tail &
\end{tabular}

TABLE IVII

HYPOTHESIS TESTING

$\mathrm{H}: \mu 1=\mu 2$ atau $\mu 1-\mu 2=0$

Artinya tidak ada perbedaan nilai Mahasiswa jika mengunakan Metode SCL

$\mathrm{H}_{\mathrm{i}}: \mu 1<\mu 2$ atau $\mu 1-\mu 2<0$

Artinya ada perbedaan nilai Mahasiswa jika mengunakan Metode SCL

$\mu=$ mean variabel
Menghitung Z Tabel dengan tingkat signifikansi adalah $5 \%$ dibagi 2 karena mengunakan dua sisi

$5 \% / 2=2,5 \%(=0,025 \%)$

luas kurva adalah $0,5-0,025=0,475$

$100 \%$ dari z tabel didapat angka untuk 0,475 adalah 1,96

untuk z Hitung didapat angka : - 41,1093

\section{Pengambilan keputusan}

dengan membandingkan $z$ Hitung dengan $z$ Tabel

- jika z Hitung > z Tabel, Hi ditolak

- jika z Hitung < z Tabel, Hi diterima

Karena $z$ Hitung lebih kecil ( - 41,1093) dengan z Tabel ( 1,96 ) maka $H_{i}$ diterima, artinya dengan mengunakan Metode SCL ada perbedaan Nilai Mahasiswa

\section{CONCLUSIONS}

From this statistical research using kolmogororov-Smirnov we get conclusion that SCL methode has an impact for student grades. This is proven with student grades taht I summarize in table, taht right SCL Methode has shown change in grade.

With this multimedia program expected to be a reference for teachers generally especially japanese teachers, to simplify learning tools more effective and efficient.

\section{REFERENCES}

[1] D. T. Mulyadi, Percakapan Dasar Bahasa Jepang, Jakarta: Kesaint Blanc, 1995.

[2] D. J. Pribadi, Bahasa Jepang untuk Hotel dan Pariwisata. Jakarta: Kesain BlancSpringer, 2005.

[3] M. Nihongo, Japan Foundation,. 2000.

[4] M. Adimihardja, Nichijookaiwa, Bandung: Pustaka Grafika, 2001.

[5] Ohadi, Bentuk Ungkapan dari Sifat Kata Kerja, Jakarta: Kesaint Blanc, 2003.

[6] S. N. No Kiso I, Japan Foundation, 1999.

[7] S. Santoso, Aplikasi Excel dalam Statistik Bisnis, Jakarta: PT Elex Komputindo, 1998

[8] Y. Kok, 161 Teknik Profesional Flash MX 2004, Jakarta: PT Elex Komputindo, 2005. 